\title{
ARTIKEL \\ METAPHOR OF MODALITY IN CLASSROOM INTERACTION
}

Disusun dan Diajukan oleh

Raissa Sati

NIM. 2133121047

Telah diverifikasi dan dinyatakan memenuhi syarat

Untuk diunggah pada jurnal online

Medan,

September 2020

Menyetujui

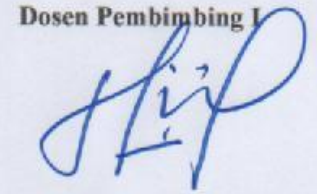

Dr. Siti Aisah Ginting, M.Pd

NIP. 195705211984032002

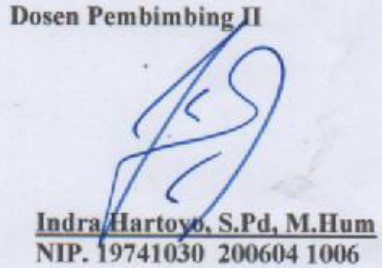

Diketahui oleh

Ka. Program Studi Pendjdikan Bahasa Inggris

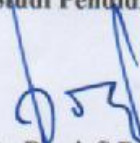

Nora Ronita Dewi, S.Pd, S.S., M.Hum.

NIP. 198005222008122003 


\title{
METAPHOR OF MODALITY IN CLASSROOM INTERACTION
}

\author{
*Raissa Sati \\ ** Dr. Siti Aisah Ginting, M.Pd \\ **Indra Hartoyo, S.Pd, M. Hum
}

\begin{abstract}
This study aims at analyzing the types and realization of metaphor of modality in classroom interaction of grade eleven Global Prima National Plus Medan. Qualitative research design was used by the researcher to conduct this study. The subjects of this study were the teacher and the students in grade eleven Global Prima National Plus Medan in academic 2018/2019. The data were collected by observed and recorded to find the types of metaphor of modality being used and also to find out how the metaphor of modality is realized in classroom interaction. The data were analyzed by using Miles and Huberman data analysis technique. The findings of the study show that teacher and students used all the types of metaphor of modality in classroom interaction, such as modalization (probability 86,79\% with 46 occurances, usuality $1,88 \%$ with 1 occurance) and modulation (obligation $3,77 \%$ with 2 occurances, inclination 7,54\% with 4 occurances). Metaphor of modality in classroom interaction was realized by the category probability (think, believe, possible), usuality (ussually), obligation (be obligied to) dan inclination (be allowed, recommend, permission).
\end{abstract}

Key words: Teaching, English, Culinary.

*Graduate Status

** Lecture Status 


\section{INTRODUCTION}

\section{Background of The Study}

Systemic Functional Linguistic (Halliday, 1994; 66) theory views grammatical metaphor as a linguistic choice and also an approach focusing on language function. SFL is a social theory of language which argues that school knowledge in constructed language, both spoken and written. Spoken and written language both play an important role in the development of educational knowledge. Halliday in his SFL theory distinguished the Standard Grammatical (congruent) and Grammatical Metaphor (non-congruent).

Grammatical metaphor that is very unlikely to be acquired outside of the academic or professional setting for a number of reasons. Firstly, generally speaking the input that oral, conversational language with which adults provide children at home tends not to include these types of constructions. Secondly, upon acquiring their first language, children interact with their environment by configuring the world around them in congruent way first. When children turn to more abstract and incongruent ways to represent reality, the condition being that they participate actively in formal settings that will provide them with rich amounts of grammatically input. Therefore, it needs to be suggested for school to introduce grammatical metaphor on the phase of transference to adolescence.

There are two types of grammatical metaphors; ideational and interpersonal metaphor based on Halliday's. The other types of grammatical metaphor are Interpersonal Metaphor. Interpersonal metaphor occurs when the 
usual or "congruent" realization of a meaning is given a non-congruent or metaphorical expression. Interpersonal metaphor can be divided into two categories, namely metaphor of mood and metaphor of modality. A second general type of interpersonal metaphor as defined by Halliday related to the area of modality.Halliday claims that modal meanings are most congruently expressed by modal element such as certainly and probably in the clause. Metaphor of modality is different from the congruent pattern in where a modal meaning is interpreted outside the proposition that is being modally assessed.

Since classroom interaction is interpersonal function of language, the researcher intended to analyze the development of the students and the teacher's language through the metaphor of modality that they used in the classroom of grade eleven Global Prima National Plus Schol Medan. Moreover, Mohan and Beckket (2012) find that in interaction, metaphor of mood and metaphor of modality is frequently used naturally by the teacher and the students which become a references in conducting this research.

Based on the integrated teaching practice program (PPLT) 2016 which was conducted by the researcher, Global Prima National Plus Medan has two classes for the grade eleven and two classes for the grade twelve. The class is divided to XI IPS and XI IPA, XII IPS and XII IPA.

This research deals with metaphor of modality in classroom interaction. The using of metaphor of modality is expected to develop student's language proficiency through the classroom interaction experience. The aim of analyzing the types of metaphor of modality and how it is realized in classroom interaction, firstly is to investigate whether the language in the classroom had 
developed which is indicated through the using modality in incongruent (metaphorical) way or they still use the modality in congruent (nonmetaphorical) way and the second is to distinguish the metaphor of modality expressions and the modality expressions. This research was conducted in GLOBAL PRIMA NATIONAL PLUS to see the metaphor of modality in classroom interaction.

\section{REVIEW OF LITERATURE}

Modality refers to how we express our evaluation about the likelihood that something will take place in reality. As Haliday and Matthiesssen (2004:618) state that there are two types of modality. They are modalization and modulation.

Modalization is realized in the expression of two kinds of meaning they are speaker's assessments of probability and usuality. Probability is used where the speakers express judgements as to thelikelihood or probability of something happening or being. The cognitive mental clause "I don't believe" or "I think" is an expression of modality. It is the metaphorical realization of probability. While usuality, it is used where the speaker express judgements as the frequency with which something happens.

Halliday\&Matthiessen (2004:618) state that modulation refers to goods and services clause(a proposal).

Modulation carries commands or offer and realized into two, they are obligation which is used to carry out the comand addressed to the second person. The scales for obligation are permissible, advisable and obligatory. 
Another modulation is inclinationwhich is the willingness of the speaker to fulfill the offer. Inclination ssignaled by: ability, willingness and determination.

Modality can be analyzed both in congruent and metaphorical forms. The use of modal finite in a clause is known as congruent modality, such as may, will, must is used to express the real opinion of a speaker.

\section{RESEARCH METHODOLOGY}

This research was conducted by descriptive qualitative research. Patton and Cochran (2002) state that qualitative research is characterized by its aims and its methods which are generate words, rather than numbers, as for its data analysis. The metaphor of modality in classroom interaction will be described with words or narratively.

The data of this study are utterances which are produced by teacher and students in classroom interaction. The source of data is the teacher and the students in grade eleven Global Prima National Plus Medan. To collect the data, the researcher will use observation to get the reliable data. In this research, the researcher will observe and record to find the types of metaphor of modality being used and also to find out how the metaphor of modality is realized in classroom interaction.

This research used interactive model proposed by Miles and Hubberman (2014:31) with three phases of data analysis. The phases are; (1) Data condensation, (2) Data Display, and (3) conclusion/verification. Data condensation refers to the process selecting, focusing, simplyfying, abstracting and transforming the role data that appear in written-up field 
notes. Selecting: in one interaction, only selected the utterance which contained the pattern of metaphor of modality. Focusing: the utterance in page 85 line 229 in the classroom interaction classified as probabilty based on Halliday's theory. Simplifying: categorized the sentence in page 85 line 229 as modalization. Abstracting: the data that had been selected and categorized had been matched with Halliday's theory.Transforming the raw data: all the data that had been selected and categorized transformed into table, because data display of this research was the table.Conclusion: after analyzed all the data in data display, the researcher made the conclusion based on the research's problems.

\section{DATA ANALYSIS}

\section{A. Types of Metaphor of Modality Used in Classroom Interaction}

The teacher's and students' utterances was recorded through the transcribtion of the clauses. Thus, there were 53 sentences from 2 different classes transcription identified as the data contained modalization and modulation

Based on data analysis, it was found that the number of metaphor of modality in classroom interaction from 2 different classes were 53 which divided into two kinds, namely modalization (probability and usuality) and modulation (obligation and inclination).

Table 4.1 The Propotion of Metaphor of Modality in Classroom Interaction

1. Probability (Modalization )

1. I think it is really easy, right? All of you just too lazy because you are micin generation. (AP3/P8/L229)

2. Gisele, you are possible to ask me futher about this topic after the 


\begin{tabular}{|c|c|}
\hline \multicolumn{2}{|c|}{ class over. (AP1/P10/L 260) } \\
\hline Teacher Utterances & 39 \\
\hline Students Utterances & 7 \\
\hline Total & 46 \\
\hline Percentage & $86.79 \%$ \\
\hline \multicolumn{2}{|c|}{ 2. Usuality (Modalization ) } \\
\hline \multicolumn{2}{|c|}{ 1. I usually told you to bring your dictionary (AP2/P8/L175) } \\
\hline Teacher Utterances & 1 \\
\hline Students Utterances & - \\
\hline Total & 1 \\
\hline Percentage & $1.88 \%$ \\
\hline \multicolumn{2}{|c|}{ 3. Obligation (Modulation ) } \\
\hline \multicolumn{2}{|c|}{ 1. You are obligated to obey my regulation (AP4/P94/L219-220) } \\
\hline Teacher Utterances & 2 \\
\hline Students Utterances & - \\
\hline Total & 2 \\
\hline Percentage & $3.77 \%$ \\
\hline \multicolumn{2}{|c|}{ 4. Inclination (Modulation ) } \\
\hline \multicolumn{2}{|c|}{$\begin{array}{l}\text { 1. I recommend you to read from unit } 1 \text { until the last unit we have } \\
\text { learnt, what unit is that?(AP4/P96/L284-285) } \\
\text { 2. It is allowed for you to do it together with your friends, } \\
\text { tapibukanmencontekyaa. (AP3/P85/L326-327) }\end{array}$} \\
\hline Teacher Utterances & 4 \\
\hline Students Utterances & - \\
\hline Total & 4 \\
\hline Percentage & $7.54 \%$ \\
\hline
\end{tabular}

Based on the table above, the number of the used of metaphor of modality was 46 . The number of probability was $86.79 \%$, usuality was $1.88 \%$, obligation was $3.77 \%$ and inclination was $7.54 \%$. It means that almost all the activities in our daily life often used metaphor of modality.

B. Realization of Metaphor of Modality in Classroom Interaction 
This section include metaphor of modality types. The realization of metaphor of modality realized in every clause. There are two categories to be analyzed in classroom interaction, namely modalization (probability and usuality) and modulation (obligation and inclination).

Table 4.2 Realization of Metaphor of Modality in Classroom Interaction

\begin{tabular}{|l|l|l|l|l|}
\hline $\begin{array}{l}\text { Metaphor of } \\
\text { Modality }\end{array}$ & Patterns & $\begin{array}{l}\text { Teacher } \\
\text { Utterances }\end{array}$ & $\begin{array}{l}\text { Students } \\
\text { Utterances }\end{array}$ & Frequency \\
\hline \multirow{3}{*}{ Probability } & Think, pikir & 22 & 7 & 29 \\
\cline { 2 - 5 } & Believe ,pasti,yakin & 13 & - & 13 \\
\cline { 2 - 5 } & $\begin{array}{l}\text { Possible, kayaknya,sepe } \\
\text { rtinya }\end{array}$ & 4 & - & 4 \\
\hline Usuality & Usually & 1 & - & 1 \\
\hline Obligation & are obligated to & 2 & - & 2 \\
\hline Inclination & is allowed & 3 & - & 3 \\
\cline { 2 - 5 } & Recommend & 1 & - & 1 \\
\hline TOTAL & 46 & 7 & 53 \\
\hline PETCENTAGE & $86,79 \%$ & $13,20 \%$ & $99,99 \%$ \\
\hline
\end{tabular}

As shown above, teacher used metaphor of modality dominantly, while students used metaphor of modality only 7 occurrences which was categorized as probability. The data above also tells us that "think" was used dominantly with 29 occurrences and followed "believe and possible" with 13 and 4 occurrences for each. The fact that the use of metaphor of modality many used contextually to achieve specific communication intents and purpose in different register. Through this amount of the use metaphor of modality is very useful strategy to describe someone's characteristic in classroom interaction. There were some types metaphor of modality used in classroom interaction.

1. Think: The meaning of think indicate someone opinion. From the table above, it is known that "think" ranked the first place with 29 occurences. Think was the first dominant used in classroom interaction. 
2. Believe: Believe indicate someone belief that something is real or true. From the table above, it is known that "believe" are the second most used in classroom intearction with 13 occurences.

3. Possible: Possible is the third place as the most common metaphor of modality used in classroom interaction with 4 occurances. The meaning of posibble involves a lower degree of belief in the truth of proposition. The use of "possible" can be used as an alternative to may, which indicates the possibility. To put other way, posibble merely indicates a little certainity about possibility.

4. Usually: Usually means in the way that is usual or normal ; most often.

5. Be obligated to: Be obligated to means being forced to do something, by law, because it is a duty. "Be obligated to" indicates a must.

6. Be allowed to: Be allowed to means being let to do something or being let something happened.Here are some sentences examples in classroom interaction.

7. Recommend: Recommend means to tell somebody that something is good or useful or that somebody would be suitable for a particular job.

\section{CONCLUSIONS AND SUGGESTIONS}

\section{Conclusion}

Based on results of data analysis, the conclusion is drawn as follows:

1. There are two types of metaphor of modality used in classroom interaction in SMA Global Prima National Plus Medan both IPA and IPS.Teacher and students used all the types of metaphor of modality in classroom 
interaction, such as modalization (probability $86,79 \%$ with 46 occurances, usuality $1,88 \%$ with 1 occurance) and modulation (obligation $3,77 \%$ with 2 occurances, inclination $7,54 \%$ with 4 occurances) .

2. Metaphor of modality in classroom interaction was realized by the category probability (think, believe, possible,if), usuality (ussually), obligation (be obligied to) dan inclination (recommend)

\section{Suggestion}

Based on the conclusion, same suggestions are presented as follows:

1. Teacher should encourage the students to express their opinion, belief, habit, obligation and their willingness to create a good classroom interaction.

2. The students should improve their vocabularies in order to maximize their English while interact in classroom both with teacher or other students. It is suggested because the students' vocabularies would affect their English and at the same time it would enable us to see wheather the students could or couldn't express their feeling such as opinion, belief, habit, obligation and their willingness while interact in classroom 


\section{REFERENCES}

Chan, Chenguang. 2001. Interpersonal Metaphor in English .Foreign Language and Their Teaching.Vol. 7 pp.6-8.

Creswell, W. 1994.Research Design: Qualitative and Quantitative Approaches. Thousand Oaks, CA: SAGE

Dagarin, Mateza. 2004. Classroom interaction and Communication Strategies in Learning as A Foreign. Sloven: Sloven University.

Dong, Jiezheng. 2013.Interpersonal Metaphor in Legal Discourse: Modality in Cross-Examinations. Journal of Language Teaching and Research, Vol. 4 No. 6, pp. 1311-1321. ISSN 1798-4769.

Ellis, R and Barkhuizen, G. 2005. Analyzing Learner Language. Oxford: Oxford University Press.

Eriba, J. O. \&Achor E. E. 2010.Effect of school type and Teacher Gender on Classroom Interaction Patterns in Integrated Science Class. Brunei International Journal of science and matemathics, 2010. Vol. 2, No. 1, PP. $48-58$

Feng and Liu. 2010. Analysis of Interpersonal Meaning in Public Speches - A Case Study of Obama's Speech.Journal of Language Teaching and Research.Vol. 1 No. 6.Pp 825-829.ISSN 1798-4769.

Halliday, M.A.K. 1984.Language as Code and Language as Behavior: A systematic functional interpretation of the nature and ontogenesis of dialogue. In: Fawcett, Robin P., M.A.K. Halliday, Sydney M. Lamb and Adam Makkai (eds). The Semiotic of Culture and Language.Vol. 1.2 Language as social semiotic. (Open Lingusitic Series.) London: Pinter, 315

Halliday, M.A.K. 1985.An Introduction To Functional Grammar. London: Edward Arnold

Halliday, M.A.K. 1994.An Introduction To Functional Grammar. $2^{\text {nd }}$ Edition. London: Arnold

Halliday, M.A.K. 2004.An Introduction To Functional Grammar. $3{ }^{\text {rd }}$ Edition.New York: Oxford University Press.

Heigham, J., \& Croker, R. A. 2009.Qualitative Research in Applied Linguistics: A practical Introduction. Basingstoke: Palgrave. Macmillan

Kothari, C.R. 1990. Research Methodology: Methods And Techniques. New Age International.

Mack, Macqueen, Guest and Namey. 2005. Qualitative Research Methods:A Data Collector's Field Guide. United States: Famili Health International (FHI). 
Moleong, Lexy. 2007. MetodologiPenelitian. Bandung: PT.RemajaRosdakarya

Patton\&Cochran.2002.A Guide to Using Qualitative Research Methodology.UnitedKingdom:Medecins Sans Frontieres.

Peng and Gao. (2015). Interpreting he Interpersonal Grammatical Metaphor in Noble Speeches in Literature. GSTF Journal on Education (JEd).Vol. 3 No. 1.

Richards, Jack C. Schmidt, Richard. 2010. Longman Dictionary of Language Teaching and Applied Linguistics. London: Longman

Rymes, Betsy. 2009. Classroom Discourse Analysis: A Tool For Critical Reflection. $2^{\text {nd }}$ Edition. New York: Routledge.

Taverniers, Miriam. (2004) Interpersonal Grammatical Metaphor as Double Scoping and Double Grounding.ModernaSpråk98(1): 17-26.

Thomas, A. Malamah. (1996).Classroom Interaction.New York: Oxford University Press.

Valipour, Valeh. Aidinlou, N.A. (2014) An Investigation of Metaphorical Modality in Barack Obama' Speeches from Systemic Functional Perspective. International Journal of Basic and Applied Science Vol. 03, No. 01, July 2014, pp. 28-33.

Wang, Qianqian. (2007). A Research on Metaphor in Advertising Language.Journal of Qufu Normal University. 48.

Xiao-hui, X. 2010.Analysis of Teacher Talk on The Basis of Relevance Theory.Canadian Social Science, 6(3), 45-50.

Xu, Jian. (2009). Interpreting Metaphor of Modality in Advertising English.CCSE Journal English Language Teaching Vol. 2 No.4. Retrieved from www.ccsenet.org/journal.html 